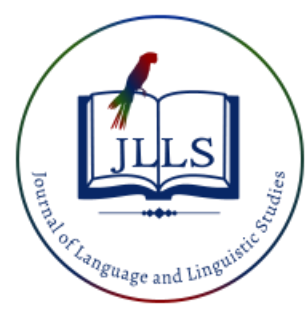

Available online at www.jlls.org

JOURNAL OF LANGUAGE AND LINGUISTIC STUDIES

ISSN: $1305-578 \mathrm{X}$

Journal of Language and Linguistic Studies, 16(4), 2113-2129; 2020

\title{
Internal stakeholders' voices for overcoming the challenges presented by studying engineering through the medium of English in Oman
}

\author{
Holi Ibrahim Holi Ali ${ }^{\text {a }}$ \\ University of Technology and Applied Sciences, Al Rustaq, Sultanate of Oman

\section{APA Citation:} \\ Holi, I. H. (2020). Internal stakeholders' voices for overcoming the challenges presented by studying engineering through the medium of \\ English in Oman: Journal of Language and Linguistic Studies, 16(4), 2113-2129. \\ Submission Date: 12/07/2020 \\ Acceptance Date:01/08/2020
}

\begin{abstract}
This current study based on a PhD study conducted by the researcher in 2018. The findings reported in this study were obtained from the analysis of interviews. The suggestions of engineering students and their English for Academic Purposes (EAP) and engineering teachers to overcome the challenges presented by studying through the medium of English will be presented and analysed. Data was analysed using thematic analysis. The research methodology employed in this study is qualitative by using methods such as semi-structured interviews. Several issues and suggestions were identified from the data set, and several themes emerged from the analysis, namely: the need to reform the school system; the need to review and restructure foundation and post-foundation programmes; the need for more strongly emphasised oral communication courses; the importance of hiring engineering teachers with high language proficiency levels; and the need to establish cooperation mechanisms between language teachers and engineering tutors, as well as to embed critical-thinking skills in English language syllabi. Both teachers and students thought the EMI issues should be considered during the foundation and postfoundation stages where students were expected to be well prepared for their speciality in terms of language proficiency and other skills.
\end{abstract}

(C) 2020 JLLS and the Authors - Published by JLLS.

Keywords: challenges; engineering; internal stakeholders; medium of English in Oman

\section{Introduction}

The English language today is not only a language to be learned for pragmatic purposes, such as education and job prospects, but it has also gone beyond that to function as the effective lingua franca for the ever-changing globalised world (Al-Issa \& Dahan, 2011). English as a medium of instruction (EMI) in higher education (HE) has become a common practice throughout most of the world to increase the internationalisation of education and to facilitate the global employability of graduates (Tatzal, 2011). There is a growing global tendency for English to be used as a medium of instruction in HE international contexts, even when the majority of the population speak a local language $(\mathrm{Vu}, 2014$, p. 2). It is generally believed that HE institutions using EMI will expand rapidly. There is intensified global

\footnotetext{
${ }^{1}$ Holi Ibrahim. Tel.

E-mail address: Holi.ibrahim.rus@cas.edu.om
} 
competition for professionals, and particularly for engineers, in the labour market, as international companies use communication in English as one of the major criteria for recruiting their staff (Cox \& Lough, 2007). Most public and private HE institutions in Oman teach science-based and humanities majors, in English (Al-Mahrooqi, 2012). The English language has institutional domains in the mass media, education and business in Oman (Al-Busaidi, 1995). Since the 1990s, English has been used as a medium of instruction in engineering and science-related disciplines to help students scaffold their English language competencies and to enable the country to succeed in implementing its vision in education and sustainable development (Al-Busaidi, 1995). The use of EMI has encouraged international cooperation and interaction between HE institutions in various fields (Crystal, 2003), however, the adoption of EMI in the English as a Foreign Language/English as a Second Language (EFL/ESL) context has created many challenges and difficulties for students. Therefore, this study was undertaken to explore Omani students', EAP and engineering teachers' perspectives on challenges faced in coping with EMI in an engineering programme in a public governmental college in Oman, and what could be done to help students overcome these challenges. Several salient EMI learning challenges were discussed in the literature (Holi, 2020; Alhassan, 2019; Wingate \& Tribble, 2012; Turner, 2012; Yousif, 2006; Lillis, 2003; Crystal, 2003; Flowerdew, Miller \& Li, 2000; Flowerdew \& Miller, 1992), namely, lecture comprehension challenges, academic literacy-related challenges, speaking and communicationrelated challenges, discipline-specific-related challenges, and in-class-related challenges.

\section{Method}

The overarching aim of the research is to explore the learning experiences of Omani engineering students studying bachelor's degrees through the medium of English at a public college in the Sultanate of Oman. More specifically, the study explores the learning experiences, challenges and problems facing these students and what their suggestions were for overcoming the challenges presented by studying engineering through the medium of English in Oman. A qualitative approach is appropriate for the questions raised by this study as it has the potential to explore engineering students' experiences when the English language is used as a medium of instruction. The research methodology employed in this study is qualitative, by using methods such as semi-structured interviews, observation and some institutional documents for data generation and collection. This study was designed to answer the following question: What are the EMI challenges encountered by Omani students by studying through the medium of English and what can be done to help students overcome their English-medium challenges? The sample includes a group of engineering students as well as engineering teachers and post-foundation EAP/ESP teachers from different departments and sections in a public college in Oman. The sample consisted of 12 students - nine male and three female - selected out of the population studying engineering as a major subject in this particular college; their ages ranged between 20 and 24 years. The engineering and EAP/ESP teachers were drawn from multiple nationalities and they have diverse teaching experiences regionally and globally. Most of them have spent an average of five years teaching in Oman. The EAP/ESP teacher participants who took part in this study were from multiple nationalities and were teaching ESP/EAP at the post-foundation level (in-sessional) in engineering and non-engineering specialities. All teachers were trained to teach English for specific and academic purposes and all have long-term experience in teaching English and academic literacies to EFL/ESL students over several years. All had a similar linguistic background, as Arabic native speakers, and had been instructed in the same educational system in Oman before they were enrolled in HE institutions in Oman. Ethical considerations were taken into account throughout the process of data generation and data analysis. The ethical issues that were taken into account in this study were permission, informed consent, confidentiality, anonymity, debrief and sensitivity. First of all, permission was sought from the 
relevant authorities and tutors concerning observing the participants in the classroom. In addition to permission, informed consent from participants is an ethical obligation for conducting research, and it is important to protect the participants from any harm (Marshall \& Rossman, 1999). All the participants were fully informed about the research process, such as the aims of the study, the research questions, the significance of the study and the importance attached to their participation. All the interviews were carried out one-to-one and face-to-face. This format was chosen because it has the potential to provide the researcher with an opportunity to listen to the interviewees' voices and to view facial expressions and physical responses which might also be significant. Face-to-face interaction provides the researcher with an opportunity to probe interviewees' responses and to obtain in-depth data (Kvale, 2007). Thematic analysis is a method for identifying, analysing and reporting patterns within data (Braun \& Clarke, 2006, p. 79). It is widely used as a qualitative analytic method, although it is rarely acknowledged (Braun \& Clarke, 2006). Moreover, it offers an accessible and theoretically flexible approach to analysing qualitative data. Thematic analysis is a generic approach that can be used with different conceptual frameworks and with descriptive exploratory studies (p. 77). It has the potential to produce more interpretations of data and offers more insightful interpretations than its counterparts with exploratory and descriptive studies.

\section{Results}

The findings of this study suggest that several steps could help to minimise EMI challenges, such as reforming the school systems, reviewing and restructuring foundation and post-foundation programmes, adopting a bilingual engineering education system (translanguaging), considering the language proficiency level of disciplinary teachers, strengthening the role of communication-related courses, integrating higher-order thinking skills into language courses and establishing cooperation mechanisms between engineering and EAP teachers.

\subsection{Reforming the school system}

Some of the students were of the view that reform should start in schools, and all science-related courses, such as physics, maths, chemistry and so on, should be taught in English to help prepare students for their future studies. For example, S2 stated that:

...I would suggest that English should be used in schools as a medium of instruction for teaching physics, maths, science and chemistry; this will help students when joining universities and colleges (S2).

S2's suggested solution involved reforming the school system by replacing the science-related medium of instruction, which is Arabic, with the English medium. This would help students gain exposure to English and science-related terminology that will assist them with their English-medium programmes in potential HE institutions if English is used to deliver these science-related subjects in Omani government schools, where all courses are taught in Arabic, and English is taught only as a subject. This is why students do not have a formal introduction to engineering and science-related terms, resulting in them encountering many language-related difficulties and problems. Participants thought that unfamiliarity with discipline-specific terms made it difficult for them to cope with their EMI demands and needs.

Another student held a similar view:

They need to start from scratch, I mean schools... They need to improve the curricula in schools and they need to increase the number of hours devoted to teaching the English language. 
Additionally, English language teachers in schools should be trained on how to teach English and they should speak only English with their students. All science-related subjects in schools should be taught in English (S1).

S1 suggested that increasing the number of hours allocated for English in schools might positively impact students' language proficiency. The suggestion that all science-related courses in schools should be delivered in English implies that all other subjects should be taught in Arabic or both languages. Participant S6 made the following comment:

I suggest that students should not be allowed to leave school and join college unless their English is up to the standard. Engineering terms should be introduced in schools and at the foundation levels. Much emphasis should be given to English in schools (S6).

This might help to enculturate students in their potential speciality. Moreover, special care and attention should be paid to the English language during the school stage.

S10 suggested the following:

I think several things can be done to improve the use of English as a medium of instruction in our engineering programme and to help students to overcome their language-related problems and difficulties. First, special care should be given to the English language in the schools such as the number of contact hours and the level of exposure. Secondly, subjects such as physics, maths, chemistry and so on. They should be delivered in English particularly during post-secondary in grades 10, 11 and 12 because this will help students be familiar with science-related terms before joining their foundation programme. There should be English for engineering students, business students and so on in the foundation and post-foundation programmes. This would help teachers and students be more focused on discipline-specific English that they need in their speciality, and at the same time, there should be some general English courses that could help students communicate effectively with their clients and customers (S10).

Several other suggestions were made by students. First, English should be paid particular attention during schooling in terms of the number of contact hours and exposure. Second, subjects such as maths, physics, chemistry and biology should be delivered in English in schools, particularly at the postsecondary grades 10,11 and 12, as this would help students become familiar with scientific terms and the engineering-associated register and jargon. Third, foundation and post-foundation courses should be discipline-oriented - there should be English for engineering, business, humanities and IT students. This would help teachers to be more focused and equip students with the necessary disciplinary knowledge and expertise. Additionally, there should be general English courses that help students develop their communication skills where they could communicate effectively with their teachers and classmates across the campus, as well as customers and clients in the workplace.

On the other hand, one student was critical of the use of EMI. He suggested bilingual engineering education as an alternative for helping students overcome their language-related problems:

Reform should start in schools, and both English and Arabic should be used within the specific degree programme. Students can choose the language medium they like, but still, English is important and it should be given special care, even with the Arabic-medium programme, to help students read and write in English effectively. Engineering teachers who are bilingual and speak Arabic and English should be given the priority because they understand their students in a better way and can explain things in Arabic which are difficult to be explained in English. General English or every day should be taught regularly across the degree to help engineering graduates to become good communicators. The methods of teaching and ways of delivery should be changed in more innovative and creative ways (S4). 
Having both English-medium and Arabic-medium programmes is not an easy option, as it would require resources and more budgets. Besides, teaching methods need to be reconsidered to accommodate students' learning preferences and strategies. Adopting current trends in teaching methodologies could help students overcome their learning problems and difficulties.

\subsection{Reviewing and restructuring foundation and post-foundation programmes}

The participants in this study stressed the importance of reviewing and restructuring foundation and post-foundation programmes. S2 suggested that:

There should be a separate foundation programme for engineering students and all the materials, whether reading or writing, should be oriented to engineering. All key technical terms should be embedded within the foundation programme because the moment that students joined their speciality they wouldn't find much difficulty in understanding these key concepts. Also, the number of post-foundation courses should be increased to six instead of four and public speaking should be taught until graduation.

The four current foundation courses referred to above are: Technical Writing I (TWI), Technical Writing II (TWII), Technical Communication (TC) and Public Speaking (PS).

Finally, it was suggested that public speaking should be offered across the entire degree programme to help students improve their oral communication skills and cope with their EMI challenges.

The post-foundation programme has equipped us with necessary academic skills such as how to write a report, how to write an essay, how to reference, how to quote, how to paraphrase, how to speak in public and how to describe equipment or to give technical explanations. However, the post-foundation programme needs to be reviewed and restructured to meet the students' academic needs. Some courses are repeated and there is no need for them. More emphasis and focus should be given to speaking and communication skills. Technical terminologies should be introduced earlier to enable students to be familiar with them (S3).

This student clarified his expectations about the post-foundation programme that was expected to equip students with some necessary academic study skills, such as report and essay writing, citation skills, how to reference, how to quote and paraphrase, how to speak English in public, how to describe equipment or gadgets, and how to give technical explanations or descriptions for something. However, it appeared that some of these necessary academic skills were overlooked by foundation and postfoundation programmes. These courses and materials need to be needs-responsive to bridge the gap between academic study needs and the needs of the labour market (Holi, 2013). Teachers stressed the need for reviewing and revising foundation programmes; communication and speaking-related courses should be given more emphasis within the degree courses.

Furthermore, a student stated:

... I would suggest addressing the problem from scratch...by improving the provision of English in schools and the foundation year. The students should be equipped with the necessary skills and attributes before joining their speciality. Post-foundation courses should be tailored according to students' specialities and needs. For example, there should be a special foundation and postfoundation courses for business students and some other courses for engineering students because they need to be familiar with their technical vocabulary and key terminologies before joining their speciality. There should be study skills courses that can help in their studies such as note-taking, problem-solving activities, critical-thinking exercises, puzzles and games which can make learning a bit fun and useful (S4). 
Indeed, some students believed that the only possible solution would be through addressing the problem from its roots by improving the provision of English language courses in schools and foundation programmes. Additionally, it was suggested that students should be equipped with the necessary skills and attributes that could enable them to function effectively in their studies before joining their degree programme. Furthermore, there should be a study skills course that incorporates skills such as note-taking, problem-solving and critical-thinking activities. These kinds of activities might help students to be more engaged in their learning and studies.

A student believed that the solution might well originate from students themselves:

Well...I think the best solution can come from the students themselves. The internet is the best solution to this problem, and the aptitude for learning is something of utmost importance. However, some factors have to do with the teacher and the syllabus. I think the syllabus is not strong enough, and the numbers of hours that are allocated for teaching are not enough for learning English. The moment students join the college they will be familiar with most of the terms and concepts. All these subjects are taught in Arabic, and therefore students find them difficult when they join college. Moreover, EAP/ESP courses (post-foundation) should be geared to engineering rather than to teaching general English. Public speaking should be taught throughout the degree because it is the most useful course that students need in their future career and everyday life (S1).

Another student expressed his views concerning the length of the foundation programme:

The post-foundation should be two years instead of one year. Students should be clustered and placed according to their speciality. Engineering students should be taught alone and special English coursebooks should be designed for them instead of having one textbook for all. English clubs and forums should be established to encourage students to speak English. Public-speaking courses should be taught during the entirety of the degree programme (S6).

It was clear that some students were not satisfied with the length of the foundation year. They believed that one year of foundation was not enough for them to study both general English as well as technical terms. This suggests that two textbooks should be used: one for general English and the other for EAP/ ESP. English clubs that provide forums for students to speak English should be established. Additionally, PS courses should be taught along with the entire degree programme due to their importance and significance for students' futures.

\subsection{Adopting a bilingual engineering education system (translanguaging)}

The findings of this section are derived from interviews and collected documents. Data is presented to demonstrate the views and suggestions of Omani engineering students and their EAP and engineering teachers on strategies for overcoming EMI challenges in their engineering education by adopting bilingual education. The idea of bilingual education (translanguaging) is supported by Barnard (2014), who argued that most Asian EFL/ESL students cannot critically engage with academic content delivered through the medium of English. Thus, he suggested that bilingual education would better prepare students to meet the challenges of today's globalised world. A student suggested that the solution could be having two engineering syllabi, involving an Arabic engineering textbook and an English engineering textbook:

I would suggest having two textbooks for each core subject. One is in Arabic and the other is in English. Those who find it difficult to understand things in English can opt for the Arabic option. This would help them study their core subjects in a good way. However, all engineering students should study English and should speak fluently. There should be a learning environment conducive 
for studying English and the number of hours allocated for studying English should be increased (S9).

However, English proficiency is still necessary for all students as they have to speak English fluently, whether they are studying through the medium of English or Arabic. Moreover, the student's suggestion that the number of English contact hours should be increased to meet student study needs and demands, as mentioned before, has resource implications.

On the other hand, S9 made the following comments:

I would suggest that engineering should be taught in English only, and Arabic shouldn't be used in class to help shy students to speak the language. Moreover, the post-foundation courses should be increased, and they should be taught along with the degree courses across the programme. All English courses within the degree should be assessed and credited. The foundation, postfoundation and core subjects should be linked together to support each other and should be based on students' real and exact needs. English clubs and forums should be established to help students practise their English regularly. English textbooks should be reviewed and updated regularly based on needs analysis to meet the students' and the job market's needs. Students should be encouraged to speak English with each other and with their teachers instead of using broken Arabic. Technical writing courses should be different from foundation writing courses (S9).

This student was critical about the use of Arabic, perhaps because of his own relatively high levels of competence in English.

\subsection{Considering the language proficiency level of disciplinary teachers}

The majority of interviewees expressed concerns regarding their English language proficiency. A student commented:

Core subjects' teachers should be carefully selected and their high English proficiency must be one of the requirements for accepting them to be teachers in an English-medium programme (S4).

The above interview extract is indicative of students' concerns about the level of subject teachers' English language proficiency. This suggests that when recruiting engineering teachers there is a need to consider the level of their language proficiency as a key factor in the selection process in addition to their disciplinary knowledge and other recruitment requirements. Teaching in an English-medium programme requires a high level of language proficiency to help students overcome their languagerelated challenges. Some of the students believed that both the language and engineering teachers are equally responsible for helping them with their language difficulties and correcting their language errors and mistakes:

...I think engineering teachers should help students with their language problems, and they should correct their language mistakes because this will help students improve their language competence (S3).

S3's experiences suggest that his language teachers should help him with his language problems, and should even correct his mistakes as he believed that this might help him improve his language competency.

Similarly, a student raised the issue of subject teachers' training on how to deliver courses through the medium of English: 
Engineering teachers should be trained in how to teach engineering in English, and they should be informed to help students with their English, and not only engineering. They should be informed that their job is not only engineering but also English (S5).

Students' concerns about the importance of the training of engineering teachers in how to use EMI to deliver their engineering courses efficiently is of vital importance. This suggests that engineering teachers need to be made aware that developing students' language proficiency and helping them to handle their language-related problems should be a shared responsibility between both language teachers and engineering teachers.

Another student expressed:

Engineering instructors and lecturers should be trained in how to teach engineering in English, and they should have a good command of English to teach engineering successfully (S1).

For this student participant, training engineering lecturers in how to teach engineering through the medium of English was important.

S8 was critical about teaching styles and the existing methodology:

The way of teaching should be changed. Teachers usually do most of the talking in class and students just listen passively. I think teachers need to engage their students in speaking by creating good, engaging activities and tasks. Engineering texts should be introduced during the foundation and post-foundation years to familiarise students with technical terms and the associated engineering register. Students should be encouraged to use English on campus. Study skills courses should be taught and assessed across the degree programme (S8).

The above interview extract suggests the need for a student-centred approach. Additionally, it was suggested that the key engineering terms should be introduced during the foundation and postfoundation years. Moreover, teachers should encourage their students to speak English while they are on campus, and study skills courses should be taught and assessed explicitly across the degree course due to their importance and significance.

Another student reflected on who is responsible for helping students handle their language-related problems:

Both English language teachers and engineering teachers should help students with their English.

They need to correct their writing and speaking errors and give them feedback accordingly.

Teaching English should be addressed during core subject lectures, labs and office hours as this would help students realise the importance of English as a medium of instruction and the primary language of communication within college premises (S7).

It can be argued that based on the above quote, both English language and engineering teachers should work together as a team to help students with English. They both need to correct their students' errors and give them feedback on their work.

The evidence gathered through interviews and observations strongly suggests that there should be a criterion for benchmarking and assessing teachers' language proficiency levels before appointing them. This would help content teachers to assist their students with language during lectures and lab sessions and would improve the quality of written feedback.

\subsection{Strengthening the role of communication-related courses}

The data illustrates the need for strengthening the role of communication-related courses within foundation and degree courses. One student claimed that engineering students need to be made aware of the importance of English for their studies and their future careers: 
... I think the most important thing for engineering students to do is to consider English as equally important to their engineering subjects. They need to give much time to their English and communication skills because technical knowledge alone is not enough for carrying out your engineering job. Foundation courses should be linked up with the speciality and speciality key terms should be introduced during the foundation year to help students survive their speciality and degree. Study skills courses should be given great emphasis through the entirety of the degree.

EAP/ESP courses should be tailored to students' academic and study needs (S5).

Students need to appreciate the importance of English in terms of their future employability. They need to give more time to their English studies because they are as important as their engineering studies. Having technical knowledge is not enough to secure a job in the future; communication skills are equally important in the job market. Therefore, HEIs need to tailor their courses and programmes based on their students' academic needs and the changing labour market demands.

In the same vein, a student added:

English communication courses should be given more emphasis than other courses as the graduates need them in the job market. Key technical terms should be introduced in schools and in the foundation and post-foundation years to familiarise students with them before they join their speciality (S9).

Another student stated:

Communication and speaking courses should be taught across the whole degree programme because they are important for students' future employability (S4).

This suggests that engineering colleges must consider such courses when formulating their policies, designing their syllabi and developing their teaching materials. It is not enough to rely on foundation courses to equip students with the necessary skills - they should also be embedded within the content courses.

\subsection{Establishing cooperation mechanisms between engineering and EAP teachers}

All participants highlighted the importance of establishing cooperation mechanisms between EAP teachers and engineering tutors to share information about students' progress, any learning difficulties and their needs in terms of skills and attributes required in their engineering classes. It seems there is no formal cooperation between EAP teachers and engineering teachers due to the absence of structured mechanisms within the Omani colleges of technology. The institutional support for such cooperation is of vital importance to ensure that EAP courses are geared towards skills, attributes and needs required by engineering programmes, as this would necessitate that EAP courses should cater for students' needs in their academic courses and their potential workplace. This cooperation could potentially bridge the gap between EAP courses and engineering courses which would encourage students to be engaged in their content courses. An EAP teacher expressed his concerns about the lack of contact and cooperation between EAP and engineering teachers due to two reasons:

One year ago I taught technical writing, and I found a lot of engineering terms, engineering stuff there when I wanted to teach. And I felt like I need to sit with engineering teachers in the department to see which of these were important for our students (or not). But because of the pressure at that time, we didn't have time to do that. So I think they should tell us which areas we need to focus on, what are things that their students need [to improve to cope with their engineering study] so that we can work together. I think [improving student language abilities] to some extent is a shared responsibility, but when it comes to the first stages it is our responsibility as English language teachers. The basics should be corrected by us, and the students should be strong [before joining their degree]. At later stages, it is the engineering department's responsibility to encourage 
students to read a lot, to research a lot and this will reflect also on their linguistic abilities (EAP T1).

A key constraint that must be considered with regards to cooperation between EAP and engineering teachers is lack of time. The EAP teacher above was of the view that cooperation is important and it was important for him to sit with an engineering teacher to help with understanding the meaning of some engineering-related technical terms; however, EAP teacher was busy and could not meet up. The EAP teacher believed that cooperation is important and saw improving students' language proficiency as a shared responsibility between both EAP and engineering teachers:

We don't have any kind of collaboration. Students are weak even in the core subjects. We don't have any formal mechanism of contact [with the English language teacher] (Eng. T2).

Similarly, the above quote indicates the lack of cooperation and contact, however, it seems that cooperation alone cannot solve the problem, as some of the students are weak, not only in English but also in their engineering core subjects. Eng. T2 explicitly stated above that they did not have any sort of contact with language teachers as they do not have any formal mechanism for cooperation and collaboration.

On the contrary, some engineering teachers expressed that they did talk to language teachers about their engineering students' difficulties and problems, but these conversations were informal.

I sometimes talk to language teachers as I have some friends who are teaching in English [at the language centre]. Yeah, sometimes we talk and we discuss things related to students' difficulties, but we don't have a formal mechanism (Eng. T5).

The above quote confirms that there were no formal cooperation mechanisms between the two parties, despite them operating in the same college, but two different departments.

\subsection{Integrating higher-order thinking skills into language courses}

The findings concerning students' suggestions with regards to embedding critical-thinking skills into the foundation courses' syllabi were based on data generated through interviews and observations. Higher-order thinking skills have become a major issue in contemporary education as they appear to hold so much promise for the individual and society (Fleming, Garcia \& Morning, 1995). Higher-order thinking skills appear to be important for students to overcome the challenges presented by the use of English in their engineering education, and to develop and build their knowledge capacity, since critical and higher-order thinking involves a variety of skills, such as self-regulation, application of multiple criteria, analysis, synthesis, identifying the source of information, analysing the credibility, reflecting on the new information and drawing conclusions based on evidence (Linn, 2000; Resnick, 1987).

The need for students to develop critical-thinking skills recurred in the data. Engineering students need these higher-order thinking and problem-solving skills to deal with engineering-related technical problems and reinforce their understanding of their disciplinary content. Critical thinking fosters students' critical attitudes which may help a learner to reflect in such a way as to be able to question, interpret, analyse and judge others' ideas (Shaheen, 2012).

An engineering teacher stated:

During their schooling, they can enrol them in critical thinking as well as analytical sounding capabilities and so on. It can be done from the schooling level. Of course, many countries are developing these skills during, in school, school days and they can improve those skills in college. That can be done. If this could be done automatically whatever we face, the problems in college can be automatically solved (Eng. T4). 
Engineering teachers perceived critical thinking as important for engineering students to study and work in the engineering industry and the labour market.

Moreover, the view of the importance of critical thinking for engineering education was stated by a student:

There should be courses during the foundation year that help students with how to solve problems and how to think critically (S7).

These comments highlight the fact that higher-order thinking skills are significant during the foundation and post-foundation stages as they could help students analyse and synthesise technical issues and facilitate their understanding in their English classes. An engineering teacher suggested:

If they can tailor materials, for example, to the students [who] are going to engineering. If they can also tailor the curriculum for a specialisation, that would be very good for students to be able to cope and to study (Eng. T2).

This is essentially the same suggestion that was made by another participant, noting how gearing EAP materials towards specialisation by integrating critical-thinking skills is important, as it has an impact on students' language-related problems that are presented by EMI. Foundation and postfoundation courses require rigorous review and revision to develop students' higher-order thinking skills that are needed in their academic and workplace settings. Equipping students with a domain of specific knowledge is not enough for them to successfully study engineering. Moreover, higher-order thinking skills could be integrated into study skills courses, which are offered during the foundation and postfoundation stages, as they are important for building students' disciplinary knowledge. One of the students expressed the importance of these courses for academic needs:

Study skills courses should be given great emphasis through the entirety of the degree. EAP/ESP courses should be tailored to students' academic and study needs (S5).

Having presented and analysed the data on how the participants perceived suggestions for overcoming challenges presented by EMI, the data analysis was centred on five study questions which progressively emerged as the most salient and frequent issues in the data set. The next chapter will discuss the findings of the study's relationship to the existing relevant literature.

\section{Discussion}

\subsection{Overcoming the challenges inherent in English-medium engineering programmes in Oman}

Several suggestions were made by the participating engineering students, EAP teachers and engineering teachers for overcoming the challenges resulting from studying engineering through the medium of English in Oman. Some students seem to have given thought to their difficulties and had constructive suggestions to make.

The existence of foundation programmes lasting between one and one-and-a-half years across Oman is clear proof that students leave secondary education unprepared for tertiary education. The same could be said about their unpreparedness for any type of employment, be it vocational or clerical. This resonates with the findings of Troudi and Jendli (2011), who investigated Emirati university students' EMI-related challenges and found that students who had attended private English-medium schools were more prepared to face the academic demands of studying in English than their colleagues who had attended governmental Arabic-medium schools. The language gap between Arabic-medium secondary schools and English-medium tertiary institutions is currently too high for Gulf students to successfully cope with. The ministries responsible for tertiary education in the case of this research - for engineering 
programmes in Omani colleges of technology - need to create a language support infrastructure that can help to bridge the gap between general education in schools and EMI engineering programmes in colleges (Lawrence, Inbar-Lourie \& Weinberg, 2017). However, since this study was focused on students' and teachers' perceptions, this is not the place to directly delve into issues about the system and, more specifically, to the Ministry of Manpower, under which the colleges of technology have been grouped.

Teachers and students, each in their own way, and based on their perceptions, spoke of the need to reform higher education. Three main wishes were stated: (1) to see communication-related courses being given more prominence, (2) to see higher-order thinking skills being integrated into language courses, and (3) to see Arabic-English bilingualism being formally accepted in Omani colleges. These transferable skills were not fully embedded within the foundation and post-foundation courses.

Time and time again, students regretted that they could not express themselves effectively in English. Their perception that communication matters, even to engineers, has repeatedly been confirmed by researchers. For example, Missingham (2006) underlined the importance of the role played by communicative competence in professional success within the engineering industry. Consequently, many researchers believe that an inter-disciplinary approach to teaching and learning in engineering programmes should combine communication and design courses in holistic ways. In other words, communication skills should not only be taught explicitly in specially designed courses but also be integrated within core courses. The emphasis on communication would be thwarted if it did not provoke reflection about the content and depth of the communication process. It has become increasingly apparent in the current climate of 'fake news' that it is not enough to merely be 'saying something' if it is incorrect, a lie or not accurately thought through. People need to receive news and knowledge with a critical and open mind. Hence, the present study confirms the importance of integrating communication and higher-order thinking skills into the engineering programme and, more specifically, in EAP courses.

Furthermore, the interviews revealed that analytical skills, together with oral and written communication skills, were viewed by the participants as important not only for college but also for the workplace.

One of the major suggestions of the findings was that a bilingual engineering education system (translanguaging) should be adopted. After all, bilingual students face numerous challenges as they seek to develop their disciplinary knowledge, and this can be particularly challenging in content areas such as science (Esquinca, Araujo \& de la Piedra, 2014). One aspect of the Omani engineering learning experience is the students' use of Arabic (their first language) and translanguaging to cope with their English-medium engineering programmes and to communicate with their teachers and classmates. Some of the teachers indicated that they, too, combine English and Arabic when they think that this can benefit their students. Given that translanguaging is increasingly being used within the academic community as an approach to the teaching of science-related courses elsewhere (García, 2009), this raises the question as to why not do likewise in Oman. However, setting up bilingual education is easier said than done it requires material and human resources, and infrastructure. Therefore, ministries must be creative as to how they design and implement linguistically double systems as colleges could not realistically offer the same course twice - once in English and once in Arabic. Having said this, given the homogeneity of the student population of the Omani colleges of technology, where practically every student is Omani, the theory could be explained in Arabic-medium theoretical courses, while its application and practice could be taught and supervised in English. This would make sense since the absolute majority of the graduates from these colleges aim to get jobs as engineers in English-medium workplaces similar to their practical classes and workshops, rather than in academic settings similar to their theoretical classes. The literature has various examples of studies on the importance of translanguaging in higher education (Kim, Kweon \& Kim, 2016; Wahi, 2013; Lasagabaster, 2013; Macaro, 2009). The informal 
incorporation of this strategy could be beneficial for Omani EFL students with low language proficiency and problems with content courses delivered through the medium of English.

Some of the students participating in this research also suggested that the language proficiency of core subject teachers was a factor making English-medium education more difficult for them. The language proficiency of the teaching staff in English-medium programmes must be ensured. This can be problematic at times as core subject teachers often believe that they are not responsible for teaching language (Airey, 2012). However, knowing one's subject well is one thing, and being able to package said knowledge and unpack it in ways that enhance students' grasp of it is another (Lawrence, InbarLourie, \& Weinberg, 2017). Lawrence, Inbar-Lourie and Weinberg (2017) stated that "in technical subjects such as engineering and medicine, it is often the case that the teachers have researched in the field in English, thus their technical language is well developed, but their ability to answer ordinary questions and engage in a non-technical discussion may not be as effective" (p. 40). Knowledge of the technical language and the associated register is not enough for content teachers to deliver their subjects effectively. They also need to master the non-technical language necessary to communicate effectively with students and deliver content successfully. Lawrence, Inbar-Lourie and Weinberg (2017) claimed that it is noticeable that EMI content teachers make systematic linguistic errors when delivering their content, and these errors are in turn repeated by their students in their writing and presentations. Consequently, it is recommended that core subject teachers are tested before recruitment on their linguistic and methodological ability to teach through the medium of English. Furthermore, EMI induction workshops and courses should be offered to the faculty to help them hone their oral expression, classroom interaction techniques and methods of delivery.

In short, acting on the above recommendations would imply a systemic and systematic revision of the engineering programmes with one overriding pedagogical goal: how to enhance the quality of the students' and colleges' output. Achieving this might call for the reform of the school system as an interconnected whole, not only with a view to scaffold the ongoing nation-building process, but also secure the growth and sovereignty of the Omani economy by allowing Omanis to compete effectively with foreign workers and to depend less on the latter. However, some practical difficulties must be kept in mind. Reforming the school system and giving greater prominence to English and higher-order skills in pre-college education cannot be done overnight. It is also financially onerous, especially at the current time of low crude oil prices. The problems of the Chinese business students in English-medium courses, studied by Jackson (2005), were often caused by the learners' inadequate preparation during their schooling and pre-university courses. This suggests that schools and foundation courses at that time were incapable of preparing students for their disciplinary degrees in terms of their language proficiency and transferable skills. Regardless of the discipline, transferable and soft skills are of vital significance in HE, and all education systems should strive to equip their students with them. Creating on-campus English language zones, as places for students to practise their English, would be a good idea to sustain students' oral and aural communication skills, and to foster their confidence and motivation. Both EAP teachers and engineering teachers need to encourage students to speak English both on campus and outside the college. EAP teachers, in particular, need to build up good personal relationships with content teachers to create an atmosphere of trust and support to discuss the issue of students' languagerelated difficulties and problems, and suggest ways to handle these problems (Lawrence, Inbar-Lourie \& Weinberg, 2017). Nevertheless, such a pre-emptive, interactive and inter-disciplinary approach cannot be realised when the teachers' timetables have not been designed with it in mind. In short, although short-term solutions may be easier to implement, they cannot be implemented at the expense of longer-term, more systemic ones. 


\section{Conclusions}

Participants felt that there is a need for doing the following to minimise EMI challenges and difficulties experienced by Omani engineering students: reforming the school system; reviewing and restructuring foundation and post-foundation programmes; adopting a bilingual engineering education system (translanguaging); considering the language proficiency level of disciplinary teachers; strengthening the role of communication-related courses, and integrating higher-order thinking skills into language courses. This study suggests that reforming the school system in Oman could be one of the strategies for overcoming EMI challenges in HE, specifically by helping students to overcome their language-related difficulties. The reform could be done by replacing the school medium of instruction, which is Arabic, with English, particularly in teaching science-related subjects such as physics, maths, chemistry and biology. This would help students to become familiar with the associated English register and with technical terms and concepts. This would also accelerate the disciplinary enculturation process and enhance their language development. Additionally, the Omani colleges of technology need to review the current structure and content of their foundation and post-foundation programmes in terms of academic literacy skills, transferable skills, discipline-specific terms, and oral and written communication skills to meet the classroom's and industry's changing needs and demands. Engineering students need to master their disciplinary writing and speaking conventions and norms to successfully communicate with their clients across the world. The results also highlighted the importance of preuniversity courses in shaping students' experiences and perceptions of the challenges encountered by studying through the medium of English. Therefore, the EAP courses offered in the foundation and postfoundation courses need to be regularly reviewed and updated to cater for students' classroom and study needs. One of the shortcomings of EAP and literacy courses is their focus on one skill, such as writing, as was echoed by Braine (2002), who found that one of the fundamental shortcomings of academic literacy studies is their focus on writing tasks alone. Embedding disciplinary literacies within preuniversity courses and core subjects is of vital importance. Students need academic literacy and disciplinary literacy skills to learn their disciplinary subject and to demonstrate their technical knowledge and what they have learned (Lea, 2004). Having considered all these aspects, this would minimise the challenges associated with studying engineering through the medium of English and help students to handle their engineering studies more successfully. Participants were of the view that adopting a bilingual engineering education system (translanguaging) would provide students with the freedom to choose their English-medium programme based on their existing language proficiency and capability. However, this would be costly as HEIs would need to employ bilingual engineering teachers and provide engineering curricula and textbooks in both English and Arabic. Teachers need to be able to appropriately interpret bilingual phenomena and use students' L1 as a resource for learning in their classes (De Jong \& Harper, 2015), rather than seeing it as an obstacle for learning. Translanguaging has the potential to empower the critical voice and consciousness of the learner and to impact classroom participation positively (Melo-Pfeifer, 2015). Bilingual teaching can help learners to figure out the meaning of a particular vocabulary item or scientific concept (Sayer, 2013). This reflects the need to have engineering teachers with bilingual skills who can utilise students' mother tongues in some cases to help them understand certain concepts and terms which were difficult for them to understand in English. The language proficiency level of disciplinary teachers was an issue. This suggests that the role of the subject teachers should not be restricted to teaching their content courses but should also be used to help students to develop their language skills. Universities and colleges need, where appropriate, to train subject teachers in EMI methodology and pedagogy to enable them to deliver their content classes successfully.

The outcomes of this study indicate a need for strengthening the role of communication-related courses, and for integrating higher-order thinking skills into language and content courses - this would 
help students cope with their speciality more effectively. From the evidence presented, it can be argued that communication-related courses and critical-thinking courses should be offered throughout the engineering degree and that they should be taught explicitly due to their importance in the classroom and industry. Literacy courses also, particularly writing projects, speaking and reading, should include analytical and communication skills both for the academic and professional settings. This would contribute significantly to helping students handle the language-related challenges presented by studying through the medium of English. All these suggestions made by study participants could help HE institutions to establish and implement their EMI courses more effectively and this would facilitate learning content through EMI.

\section{Ethics Committee Approval}

The author confirms that the study does not need ethics committee approval according to the research integrity rules in their country (Date of Confirmation: September 12, 2020).

\section{References}

Airey, J. (2012). I don't teach language: The linguistic attitudes of physic lecturers in Sweden. AILA Review, 25(1), 64-79.

Alhassan, A. (2019). EFL postgraduate students' learning needs on English-medium business programmes: An exploratory study. Language Teaching Research, 1-19.

Barnard, R. (2014). English medium instruction in Asian universities: Some concerns and a suggested approach to dual-medium instruction. Indonesian Journal of Applied Linguistics, 4(1), 10-22.

Braine, G. (2002). Academic literacy and the non-native speaker graduate student. English for Academic Purposes, 1(1), 59-68.

Braun, V., \& Clarke, V. (2006). Using thematic analysis in psychology. Qualitative Research in Psychology, 3(2), 77-101.

Cox, L. R., \& Lough, K. G. (2007). The importance of writing skill to the engineering students, University of Arkansas-Fort Smith / University of Missouri-Rolla.

De Jong, E.J., \& Harper, C. A. (2015). Preparing Mainstream Teachers for English-Language Learners: Is Being a Good Teacher Good Enough? Teacher Education Quarterly, Spring, 100-124.

Esquinca, A., Araujo, B., \& Teresa de la Piedra, M. (2014). Meaning-making and translanguaging in a two-way dual-language program on the U.S.-Mexico border. Bilingual Research Journal, 37(2), 164-181.

Fleming, J., Garcia, N., \& Morning, C. (1995). The critical thinking skills of minority engineering students: An exploratory study. Journal of Negro Education, 64(4), 437-453.

Flowerdew, J., \& Miller, L. (1992). Student perception, problems and strategies in second language lecture comprehension. RELC Journal, 23(2), 60-80.

Flowerdew, J., Miller, L., \& Li, D., C. S. (2000). Chinese lecturers' problems and strategies in second language lecture comprehension. RELC Journal, 31(1), 116-138.

García, O. (2009). Bilingual education in the 21st century: A global perspective. Oxford: Blackwell. 
Holi, I.H. (2020). Omani students' coping strategies in an English medium engineering programme. Arab World English Journal (AWEJ), 11(2), 361-382.

Holi, I. H. (2020). Lecture comprehension difficulties experienced by Omani students in an English medium engineering programme, Cogent Arts \& Humanities, 7(1), 1-17.

Holi, I. H. (2018). Omani Engineering Students' Experiences of Learning through the medium of English (Unpublished doctoral dissertation), University of Huddersfield, UK.

Holi, I. H. (2013). Perceived views of language teachers on the use of needs analysis in ESP materials writing. English Language Teaching Journal, 6(3), 11-19.

Jackson, J. (2005). An inter-university, cross-disciplinary analysis of business education: perceptions of business faculty in Hong Kong. English for Specific Purposes, 24(3), 293-306.

Kim, E., Kweon, S., \& Kim, J. (2016). Korean engineering students' perceptions of English-medium instruction (EMI) and L1 use in EMI classes. Journal of Multilingual and Multicultural Development.

Lasagabaster, D. (2013). The use of L1 in CLIL classes: The teachers' perspective. Latin American Journal of Content and Language Integrated Learning 6(2), 10-21.

Lawrence, C., Inbar-Lourie, O., \& Weinberg, L. (2017). A handbook for English-medium instruction in institutions of higher education in Israel. Published by Tempus Programme of the European Union $1-59$.

Lea, M. R. (2004). Academic literacies: pedagogy for course design. Studies in Higher Education, 29(6), 739-756.

Lillis, T. (2003). An academic literacies approach to student writing: drawing on Bakhtin to move from critique to design. Language and Education, 17(3), 192-207.

Linn, M. C. (2000). Designing the knowledge integration environment. International Journal of Science Education, 22(8), 781-796.

Macaro, E. (2009). Teacher use of codeswitching in the second language classroom: Exploring 'optimal' use. In M. Turnbull \& J. Dailey-O'Cain (Eds.), First language use in second and foreign language learning (pp. 35-49). Clevedon: Multilingual Matters.

Marshall, C., \& Rossman, G. B. (1999). Designing qualitative research ( $3^{\text {rd }}$ ed.). Newbury Park: Sage.

Melo-Pfeifer, S. (2015). Translanguaging, language, bilingualism and education. Language and Intercultural Communication Journal, 15(1), pp.179-183.

Missingham, D. (2006). The integration of professional communication skills into engineering education. The Proceedings of the EDU-COM 2006 International Conference, Edith Cowan University, Perth Western Australia, 346-357.

Sayer, P. (2013). Translanguaging, TexMex, and bilingual pedagogy: Emergent bilinguals learning through the vernacular. TESOL Quarterly, 47(1), 63-88.

Shaheen, N. (2012). International students at UK universities: critical thinking related challenges to academic writing, University of Huddersfield (Unpublished doctoral dissertation). Retrieved from http://eprints.hud.ac.uk/16429/

Troudi, S., \& Jendli, A. (2011). Emirati students' experiences of English as a medium of instruction. In Issa, A. \& Dahan, L. (Eds.), Global English and Arabic: Issues of language, culture, and identity (pp. 23-48). 
Turner, J. (2012). Academic literacies: Providing a space for the socio-political dynamics of EAP. Journal of English for Academic Purposes, 11(1), 17-25.

Wahi, W. (2013). Reading in engineering: Understanding engineering students' English language academic literacies. International Proceedings of Economics Development and Research, 68(18), 107-112.

Wingate, U., \& Tribble, C. (2012). The best of both worlds? Towards an English for Academic Purposes/Academic Literacies Writing Pedagogy. Studies in Higher Education, 37(4), 481-495.

Yousif, A. A. (2006). Listening Comprehension Difficulties as Perceived by. Journal of King Saud University Language and Translation, 19, 35-47.

\title{
Umman'da İngilizce aracılığıyla mühendislik eğitimi almanın getirdiğ zorlukların üstesinden gelmek için iç paydaşların sesleri
}

\begin{abstract}
$\ddot{O} \mathbf{z}$
Bu çalışma, araştırmacı tarafından 2018 yılında yapılan bir doktora çalışmasına dayanmaktadır. Bu çalışmada bildirilen bulgular görüşmelerin analizinden elde edilmiştir. Mühendislik öğrencilerinin ve onların Akademik Amaçlı İngilizce (EAP) ve mühendislik öğretmenlerinin İngilizce dilinde çalışarak ortaya çıkan zorlukların üstesinden gelmeleri için önerileri sunulacak ve analiz edilecektir. Veriler tematik analiz kullanılarak analiz edildi. Nitel araştırma yöntemi kullanılmıştır. Veri setinden birkaç konu ve öneri belirlendi ve analizde birkaç tema ortaya çıktı, bunlar: okul sisteminde reform ihtiyacı; kuruluş ve kuruluş sonrası programları gözden geçirme ve yeniden yapılandırma ihtiyacı; daha güçlü vurgulanan sözlü iletişim kurslarına duyulan ihtiyaç; yüksek dil yeterlilik düzeyine sahip mühendislik öğretmenlerinin işe alınmasının önemi; ve dil öğretmenleri ile mühendislik öğretmenleri arasında işbirliği mekanizmaları kurma ve ayrıca eleştirel düşünme becerilerini İngilizce müfredatına yerleştirme ihtiyacı. Hem öğretmenler hem de öğrenciler, EMI konularının, öğrencilerin dil yeterliliği ve diğer beceriler açısından uzmanlık alanlarına iyi hazırlanmalarının beklendiği kuruluş ve kuruluş sonrası aşamalarda dikkate alınması gerektiğini düşündüler.
\end{abstract}

Anahtar Sözcükler: zorluklar; mühendislik; iç paydaşlar; Eğitim dili İngilizce

\section{AUTHOR BIODATA}

Holi Ibrahim Holi Ali is an assistant professor of applied linguistics \& TESOL at the Department of English Language \& Literature in the University of Technology and Applied Sciences, Rustaq, Sultanate of Oman. He has a PhD in applied linguistics from the University of Huddersfield, UK. His teaching and research interests include English-medium instruction (EMI) and TESOL. He has presented widely and published extensively in peerreviewed journals. 